\title{
EUROPEAN MEDICINES AGENCY
}

SCIENCE MEDICINES HEALTH

18 February 2013

EMA/COMP/798800/2012

Committee for Orphan Medicinal Products

\section{Public summary of opinion on orphan designation Eflornithine in combination with sulindac for the treatment of familial adenomatous polyposis}

On 24 January 2013, orphan designation (EU/3/12/1086) was granted by the European Commission to Cancer Prevention Pharma Limited, United Kingdom, for eflornithine in combination with sulindac for the treatment of familial adenomatous polyposis.

\section{What is familial adenomatous polyposis?}

Familial adenomatous polyposis (FAP) is a hereditary disease in which numerous polyps (growths) form in the gut, mainly in the large intestine. Polyps usually start to develop in late childhood and their number varies from hundreds to thousands. Patients with FAP may have blood in the stools, diarrhoea or constipation, abdominal pain (stomach ache) and weight loss with no obvious cause.

FAP is a long-term debilitating disease that may be life threatening because there is a high risk of it progressing into cancer of the large intestine if it is not treated, and can cause problems outside the gut including stomach problems and other types of cancer.

\section{What is the estimated number of patients affected by the condition?}

At the time of designation, FAP affected approximately 0.2 in 10,000 people in the European Union (EU). This was equivalent to a total of around 10,000 people*, and is below the ceiling for orphan designation, which is 5 people in 10,000. This is based on the information provided by the sponsor and the knowledge of the Committee for Orphan Medicinal Products (COMP).

\section{What treatments are available?}

At the time of designation, no satisfactory methods were authorised in the EU for the treatment of FAP. Some patients were given preventive surgery to remove parts of the large bowel in order to prevent polyps from progressing into cancers.

*Disclaimer: For the purpose of the designation, the number of patients affected by the condition is estimated and assessed on the basis of data from the European Union (EU 27), Norway, Iceland and Liechtenstein. This represents a population of 509,000,000 (Eurostat 2013). 


\section{How is this medicine expected to work?}

This medicine is made up of two substances, eflornithine and sulindac:

- Eflornithine works by blocking the action of an enzyme called ornithine decarboxylase, which is involved in the production of substances called polyamines that are required for cells to grow. In patients with FAP, ornithine decarboxylase is over-activated and this has been linked with the rapid growth of polyp cells. By blocking the enzyme, eflornithine is expected to slow down the cell growth.

- Sulindac works by activating an enzyme called SSAT that expels polyamines from intestinal cells. This is expected to reduce the levels of polyamine in the intestine, thereby reducing the cell growth and improving the symptoms of the disease.

The combination of the two substances is expected to have an additive effect, slowing down the growth of the polyps more than either substance alone.

\section{What is the stage of development of this medicine?}

The effects of the medicine have been evaluated in experimental models.

At the time of submission of the application for orphan designation, clinical trials with the medicine in patients with FAP were being initiated.

At the time of submission, the medicine was not authorised anywhere in the EU for FAP. Eflornithine and sulindac received orphan designation in the United States of America for the treatment of FAP.

In accordance with Regulation (EC) No 141/2000 of 16 December 1999, the COMP adopted a positive opinion on 6 December 2012 recommending the granting of this designation.

Opinions on orphan medicinal product designations are based on the following three criteria:

- the seriousness of the condition;

- the existence of alternative methods of diagnosis, prevention or treatment;

- either the rarity of the condition (affecting not more than 5 in 10,000 people in the EU) or insufficient returns on investment.

Designated orphan medicinal products are products that are still under investigation and are considered for orphan designation on the basis of potential activity. An orphan designation is not a marketing authorisation. As a consequence, demonstration of quality, safety and efficacy is necessary before a product can be granted a marketing authorisation. 


\section{For more information}

Sponsor's contact details:

Cancer Prevention Pharma Limited

c/ o Arnold \& Porter UK LLP

Tower 42

25 Old Broad Street

London, EC2N $1 \mathrm{HQ}$

United Kingdom

Telephone: +44 2077866100

Telefax: +44 2077866299

E-mail: cbrannen@canprevent.com

For contact details of patients' organisations whose activities are targeted at rare diseases see:

- $\quad$ Orphanet, a database containing information on rare diseases which includes a directory of patients' organisations registered in Europe.

- European Organisation for Rare Diseases (EURORDIS), a non-governmental alliance of patient organisations and individuals active in the field of rare diseases. 
Translations of the active ingredient and indication in all official EU languages $^{1}$, Norwegian and I celandic

\begin{tabular}{|c|c|c|}
\hline Language & Active ingredient & I ndication \\
\hline English & $\begin{array}{l}\text { Eflornithine in combination with } \\
\text { sulindac }\end{array}$ & Treatment of familial adenomatous polyposis \\
\hline Bulgarian & $\begin{array}{l}\text { Ефлорнитин в комбинация със } \\
\text { сулиндак }\end{array}$ & Лечение на Фамилна Аденоматозна Полипоза \\
\hline Czech & Eflornithin se sulindacem & Léčba familiární adenomatózní polypózy \\
\hline Danish & $\begin{array}{l}\text { Eflornithin i kombination med } \\
\text { sulindac }\end{array}$ & Behandling af familiær adenomatøs polypose \\
\hline Dutch & $\begin{array}{l}\text { Eflornithine in combinatie met } \\
\text { sulindac }\end{array}$ & $\begin{array}{l}\text { Behandeling van familiale adenomateuze } \\
\text { polyposis }\end{array}$ \\
\hline Estonian & $\begin{array}{l}\text { Eflornitiini kombinatsioonis koois } \\
\text { sulindakiga }\end{array}$ & Perekondliku adenomatoosse polüpoosi ravi \\
\hline Finnish & Eflornitiini sulindaakin kanssa & $\begin{array}{l}\text { Perinnöllisen adenomatoottisen polyyppitaudin } \\
\text { hoito }\end{array}$ \\
\hline French & $\begin{array}{l}\text { Éflornithine en combinaison avec } \\
\text { sulindac }\end{array}$ & $\begin{array}{l}\text { Traitement de la polypose adénomateuse } \\
\text { familiale }\end{array}$ \\
\hline German & $\begin{array}{l}\text { Eflornithin in Kombination mit } \\
\text { Sulindac }\end{array}$ & $\begin{array}{l}\text { Behandlung von familiärer adenomatöser } \\
\text { Polyposis }\end{array}$ \\
\hline Greek & 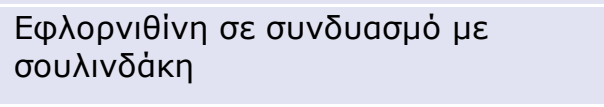 & 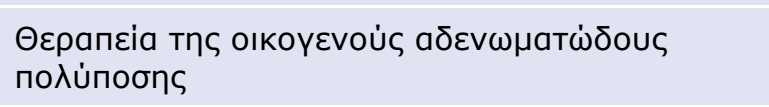 \\
\hline Hungarian & Eflornitin és szulindak kombináció & Familiáris adenomatosus polyposis kezelése \\
\hline Italian & $\begin{array}{l}\text { Eflornitina in combinazione con } \\
\text { sulindac }\end{array}$ & $\begin{array}{l}\text { Trattamento della poliposi familiare } \\
\text { adenomatosa }\end{array}$ \\
\hline Latvian & Eflornitīnakombinācijā ar sulindaku & Ģimenes adenomatozās polipozes ārstēšana \\
\hline Lithuanian & Eflornitinas derinyje su sulindaku & Šeiminès adenomatozinès polipozès gydymas \\
\hline Maltese & Eflornithine flimkien ma' sulindac & Kura tal-polipożi adenomatuża li tintiret \\
\hline Polish & $\begin{array}{l}\text { Eflornityna w skojarzeniu z } \\
\text { sulindakiem }\end{array}$ & $\begin{array}{l}\text { Leczenie Rodzinnej Polipowatości } \\
\text { Gruczolakowatej }\end{array}$ \\
\hline Portuguese & Eflornitina associada ao sulindac & Tratamento do pólipo adenomatoso familiar \\
\hline Romanian & Eflornitină in combinaţie cu sulindac & Tratamentul polipozei adenomatoase familiale \\
\hline Slovak & Eflornitín v kombinácii so sulindakom & Liečba familiárnej adenomatóznej polypózy \\
\hline Slovenian & Eflornitin v kombinaciji s sulindakom & Zdravljenje familiarne adenomatozne polipoze \\
\hline Spanish & $\begin{array}{l}\text { Eflornitina en combinación con } \\
\text { sulindac }\end{array}$ & Tratamiento de la poliposis colónica familiar \\
\hline
\end{tabular}

\footnotetext{
${ }^{1}$ At the time of designation
} 


\section{Language Active ingredient}

Swedish

Eflornitin i kombination med sulindak

Norwegian Eflornitin i kombinasjon med sulindak

Icelandic
I ndication

Behandling av familjär adenomatös polypos

Behandling av familiær adenomatøs polypose

Ættlægt adenomatös sepager 